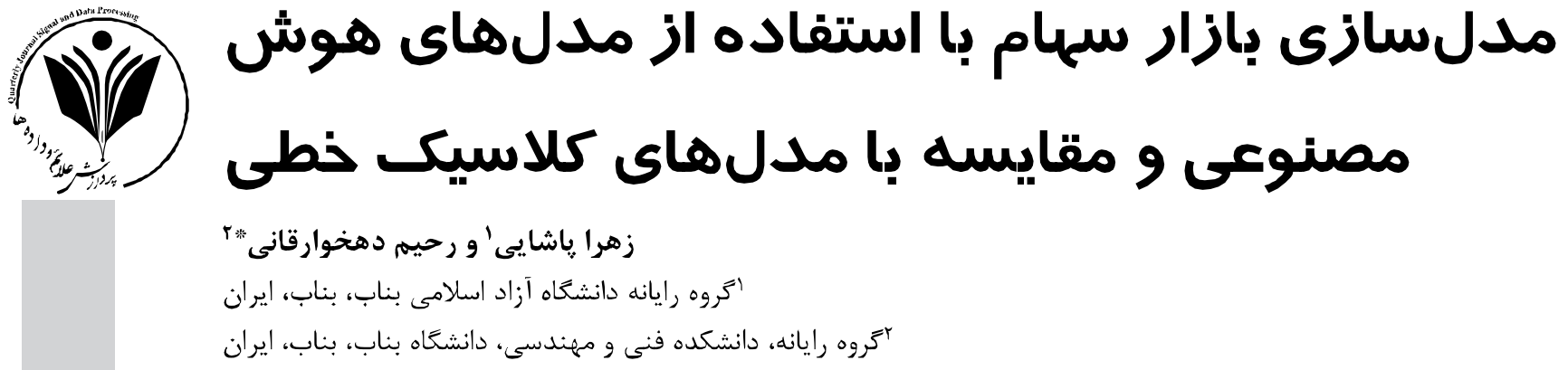

جكکبه

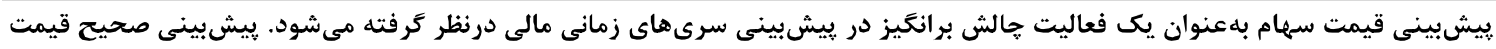

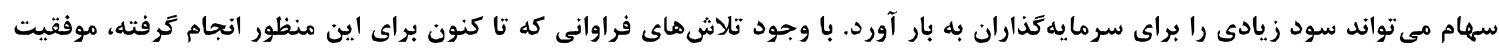

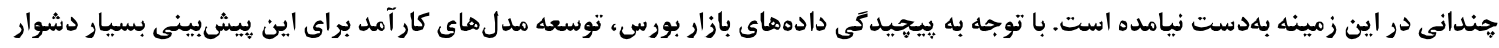

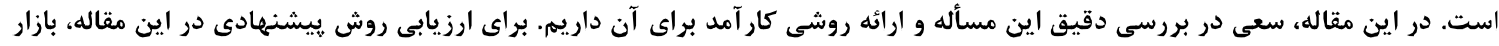

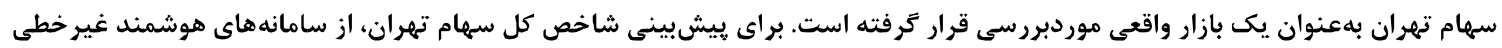

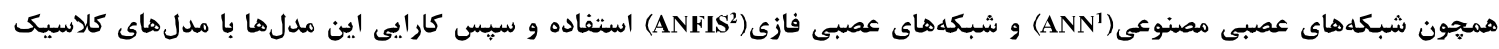
خطى) (SARIMA و بر (SARIMA

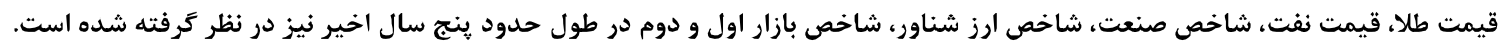

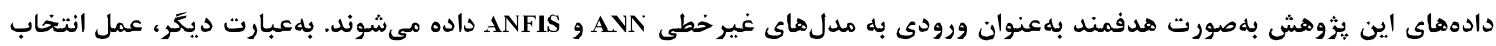

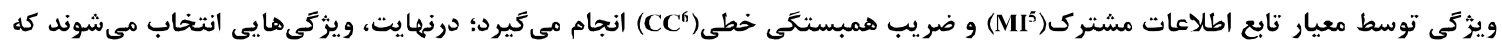

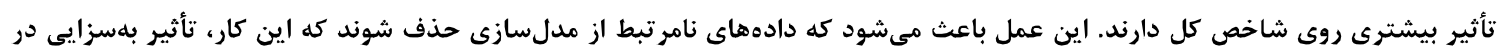

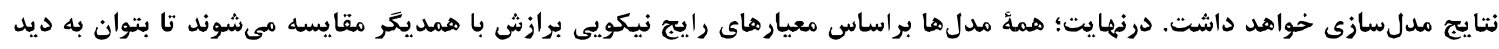

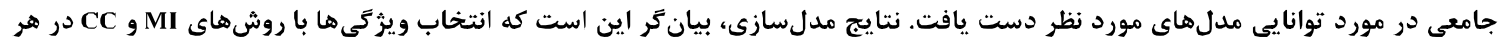

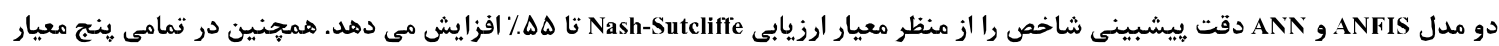

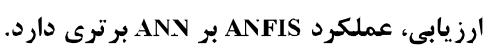

وازگًان كليدى: شاخص بازار بورس، شبكه عصبى فازى، شبكه عصبى مصنوعى، ضريب همبستكى خطى، مدل آريما و مدل ساريما

\title{
Stock Market Modeling Using Artificial Neural Network and Comparison with Classical Linear Models
}

\section{Zahra Pashaei $^{1}$ \& Rahim Dehkharghani*2}

${ }^{1}$ Faculty of Electrical and Computer Engineering, Islamic Azad University of Bonab,

Bonab, Iran

${ }^{2}$ Faculty of Engineering, University of Bonab, Bonab, Iran

${ }^{1}$ Artificial Neural Networks

${ }^{2}$ Adaptive Neural Fuzzy Inference System

${ }^{3}$ Auto Regressive Integrated Moving Average

${ }^{4}$ Seasonal Auto Regressive Integrated Moving Average

${ }^{5}$ Mutual Information

${ }^{6}$ Corrclation Cocfficient

* Corresponding author * تويسندة عهدهدار مكاتبات 


\begin{abstract}
Stock market plays an important role in the world economy. Stock market customers are interested in predicting the stock market general index price, since their income depends on this financial factor; Therefore, a reliable forecast in stock market can be extremely profitable for stockholders. Stock market prediction for financial markets has been one of the main challenges in forecasting financial time series, in recent decades. This challenge has increasingly attracted researchers from different scientific branches such as computer science, statistics, mathematics, and etc. Despite a good deal of research in this area, the achieved success is far from ideal. Due to the intrinsic complexity of financial data in stock market, designing a practical model for this prediction is a difficult task. This difficulty increases when a wide variety of financial factors affect the stock market index. In this paper, we attempt to investigate this problem and propose an effective model to solve this challenge. Tehran's stock market has been chosen as a real-world case study for this purpose. Concretely, we train a regression model by several features such as first and second market index in the last five years, as well as other influential features including US dollar price, universal gold price, petroleum price, industry index and floating currency index. Then, we use the trained system to predict the stock market index value of the following day. The proposed approach can be used by stockbrokers-trading companies that buy and sell shares for their clients to predict the stock market value. In the proposed method, intelligent nonlinear systems such as Artificial Neural Networks (ANNs) and Adaptive Network-based Fuzzy Inference System (ANFIS) have been exploited to predict the daily stock market value of Tehran's stock market. At the end, the performance of these models have been measured and compared with the linear classical models, namely, ARIMA and SARIMA. In the comparison phase, these time series data are imposed to non-linear ANN and ANFIS models; then, feature selection is applied on data to extract the more influencing features, by using mutual information (MI) and correlation coefficient (CC) criteria. As a result, those features with greater impact on prediction are selected to predict the stock market value. This task eliminates irrelevant data and minimizes the error rate. Finally, all models are compared with each other based on common evaluation criteria to provide a big picture of the exploited models. The obtained results approve that the feature selection by MI and CC methods in both ANFIS and ANN models increases the accuracy of stock market prediction up to 55 percentage points. Furthermore, ANFIS could outperform ANN in all five evaluation criteria.
\end{abstract}

Keywords: ARIMA, ANFIS, ANN, CC, MI, SARIMA, Stock Modelling.

$$
\begin{aligned}
& \text { بهترى را نسبت به روشهاى رياضى و آمارى مانند رگرسيون }
\end{aligned}
$$

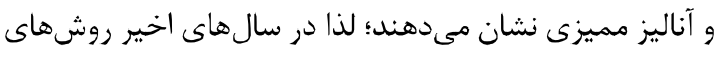

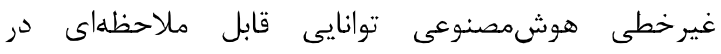

$$
\begin{aligned}
& \text { مدلسازى و يِيشبينى سرىهاى زمانى مالى از خود نشان }
\end{aligned}
$$

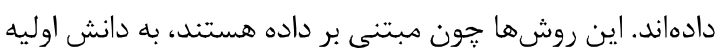

$$
\begin{aligned}
& \text { نسبت به يديدهُ مورد مطالعه نياز ندارند. مدلهاى مبتنى بر } \\
& \text { هوشمصنوعى، ابزارى كارآمد براى كاركردن بر روى تعداد }
\end{aligned}
$$

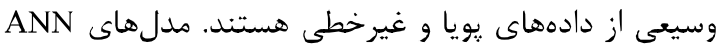

$$
\begin{aligned}
& \text { و ANFIS از جمله روشهاى هوش مصنوعى هستند كه حالت }
\end{aligned}
$$

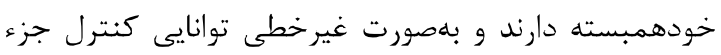

$$
\begin{aligned}
& \text { خودهمبسته سرى زمانى را دارند. }
\end{aligned}
$$$$
\text { r- بيشينه بثروهش }
$$$$
\text { در سال } 1911 \text { براى نخستينبار نظريه استفاده از شبكههاى }
$$

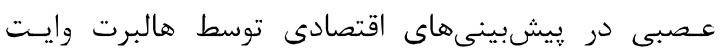

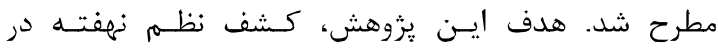

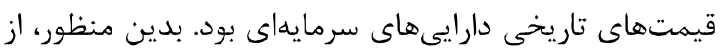

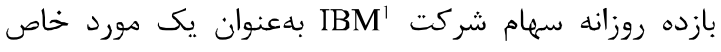

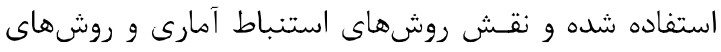

\footnotetext{
${ }^{1}$ International Business Machines Corporation
}

$$
\begin{aligned}
& \text { dolقo - } \\
& \text { از دوران كَشايش بازارهاى اوراق بهادار، انسانها همواره تلاش } \\
& \text { مى كردند تا قيمت سمام را ييشبينى كنند و در اين راه } \\
& \text { سخت|فزارها و نرمافزارهاى مختلف، تحليل هاى متفاوت مالى } \\
& \text { ابداع شده و مورد استفاده قر ار زرفتند. متخصصان باز ار سرمايه } \\
& \text { براى ساليان متمادى بازار را مطالعه كرده و الگوهايى را فرا }
\end{aligned}
$$

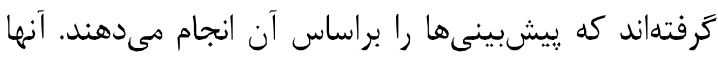

$$
\begin{aligned}
& \text { تركيبى از تشخيص الكَو و تجربه مبتنى بر مشاهده روابط علّت } \\
& \text { و معلول را بهكار مى گيرند. با اين وجود، يك قانون كلى در } \\
& \text { مورد اينكه جه اطلاعاتى مهمتر هستند، وجود ندارد. برنامه } \\
& \text { هاى نرمافزارى بسيارى نيز وجود دارند كه به اين تصميمزيرى }
\end{aligned}
$$

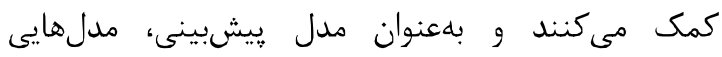

$$
\begin{aligned}
& \text { نظير ARIMA و استفاده مي شوند كه از ركرسيون } \\
& \text { خطى و ميانتين متحرك و نظاير اينها بهعنوان موتور } \\
& \text { ييشبينى استفاده مى كنند. با اين وجود در روندهاى مالى } \\
& \text { بهدليل وجود ويثزى هاى غيرخطى، اغلب شرايطى به وجود }
\end{aligned}
$$

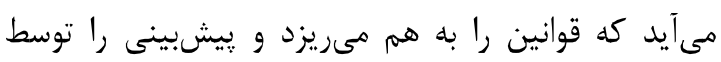

$$
\begin{aligned}
& \text { روشهـاى يادشده دشوار مىسازد. نتايج كارهاى كذشئه } \\
& \text { صورت گرفته نشان مى دهد كه مدل هاى هوش مصنوعى، نتايج }
\end{aligned}
$$

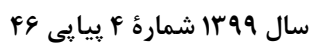


قيمت بازار سهام است [13]. در اين مقاله براى پِيشبينى

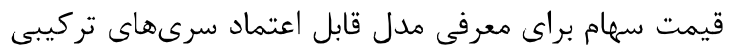
ارزيابى مىشوند كه بيان مىكنئند مدل مدل تركيبى ARIMA نتايج دقيقترى به دست مى دهد [14]

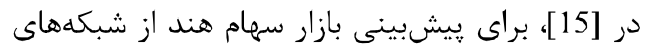

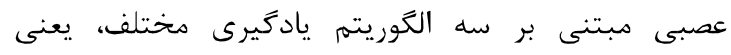
و Scaled Conjugate Gradient.Levenberg-Marquardt Regularization Bayesian استفاده شده است. در يروهشى ديخر براى مقايسه و انتخاب روشى براى يیشبينى فروش كالاهاى اساسى در بخشهاى نداى

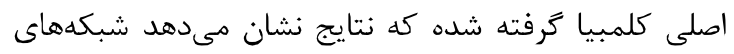
عصبى عملكرد بهترى را براى دستيابى به كمترين ميانخين

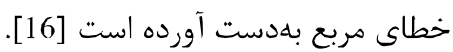

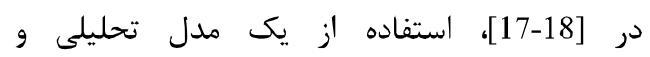
ييشبينىشده براى برآورد شاخصهاى بورس يِيشنهاد شده

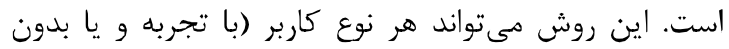
تجربه) را در بورس راهنمايى كند تا بتواند سرمايه كذارى

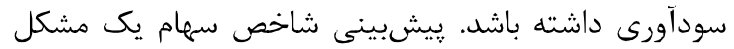

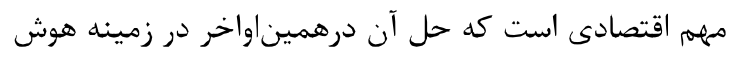

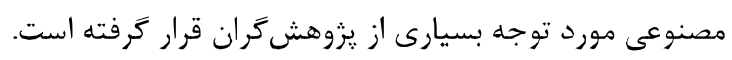

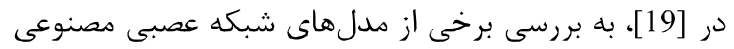

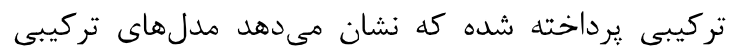

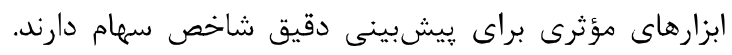

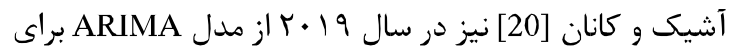
ييشبينى قيمت سهام استفاده كردهاند.

\section{ب - تعاريف و مفاهيم اوليه}

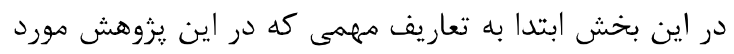

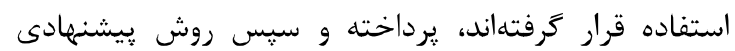

$$
\text { توضيح داده مىشود. }
$$

\section{ו-r- مدل ميانغين متحرك خودهمبسته \\ يكيار جه}

مدلهاى كلاسيك جعبئ سياه همجون ARIMA بلصورت

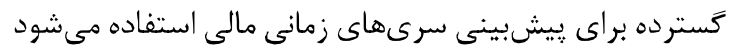
[21]. ذات اين مدل، خطى بوده و بر فرض ايستابودن دادهها استوار است [22]. مدل ARIMA توانايى شناسايى الكَوهاى

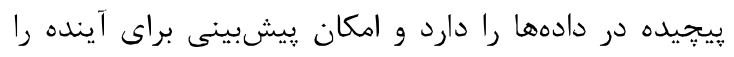
مطابق با دادهاى ورودى در زمان كذشته فراهم مى آورد [23].

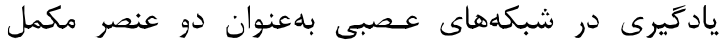

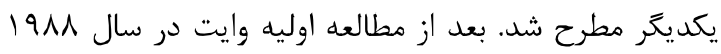

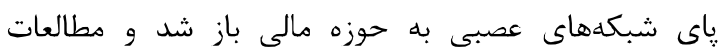
متعددى در اين زمينه در نقاط مختلف جهان صورتكائ كرفت

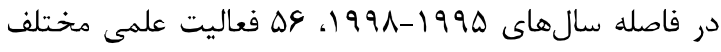
در زمينه شبكههاى عصبى در حوزه بازر كانى انجام گرفت كه

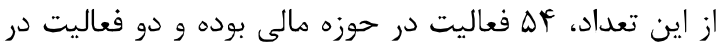
زمينه بيشبينى و تجزيه و تحليل سرىهاى زمانى إنى انجام شده

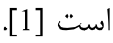

در يزوهشى ديخر، در سال •999 19، ساهانه وِيشبينى بازار سهامى ارائه شد كه در اين مطالعه ضمن درن مقايسه

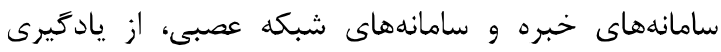

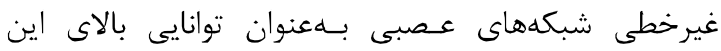

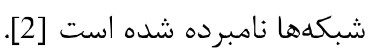

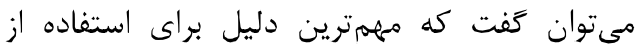
شبكدهاى عصبى، وجود مسائل بسيار زياد حل نشدنى

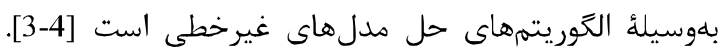
مزاياى استفاده از شبكه عصبى اين است كه افراد، نيازى به مله

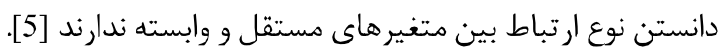

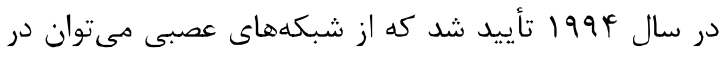

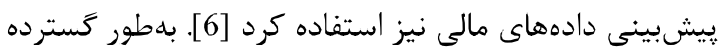

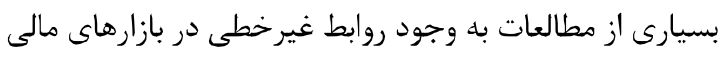
اشاره كرده و بيان كردند كه مى توان بلطور مؤثر از شبكدهاى

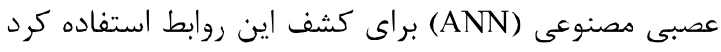

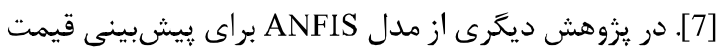

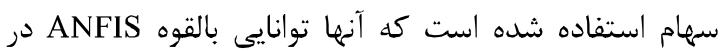
يِيشبينى شاخص سهام را تزارش كردهاند [8].

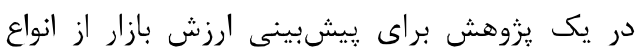

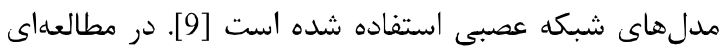
ديخر از يك مدل بيشبينى جديد بر اساس سرى زمانى فازى

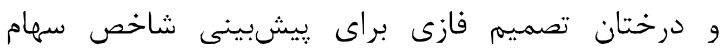

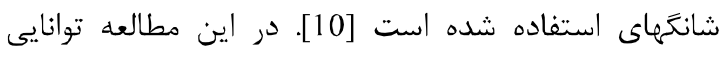
ANN

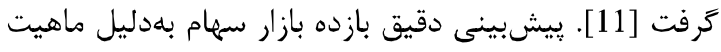

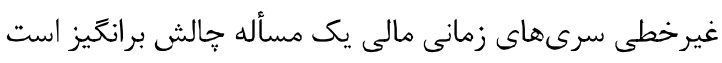

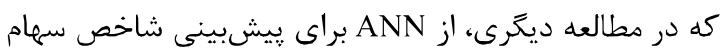
زاين استفاده شده است [12].

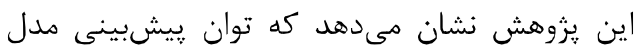

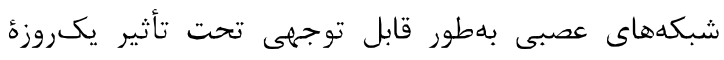


بهازاى آنها آموزش ديدهاند، جوابهاى قابل قبول ارائه دهند

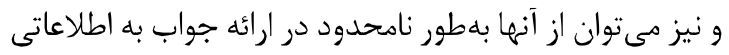

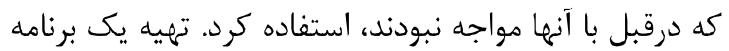

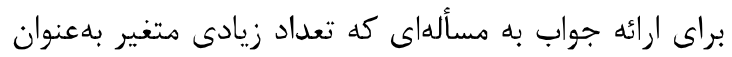

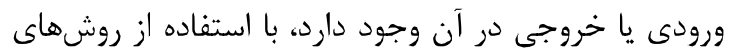

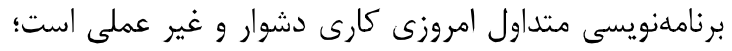

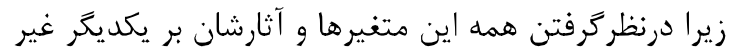

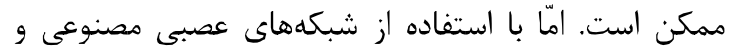

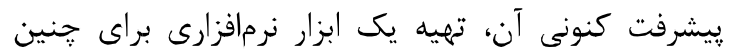

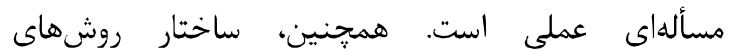
برنامهنويسى متداول امروزى بهكَونهاى است كه در صورت وجود اشتباه در اطلاعات ورودى، تمامى محاسبات ممكن

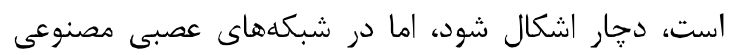

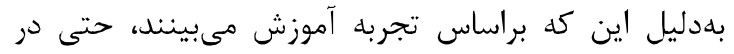
صورت وجود اشتباه در اطلاعات ورودى، شبكه بهطور قابل ملاحظهاى قابليت تحمل خطا خواهد داشت.

\section{r-r-r- شرايط دادههاى ورودى}

براى تربيت شبكههاى عصبى احتياج به مجموعهدادههاى

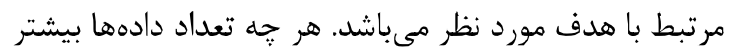
باشد، مى توان ويشبينى در زمينهى مورد نظر رادقيقتر انجام

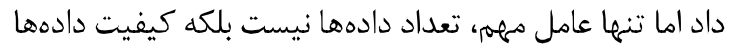

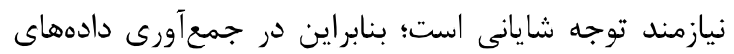

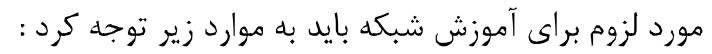

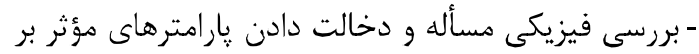

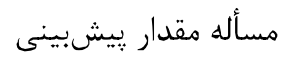
- اطمينان از كيفيت دادههاى مورد استفاده از لحاظ كيفيت

و قابليت اعتماد [24].

براى هماهنگسازى نوع و محدودة دادهها بهمنظور إنماد

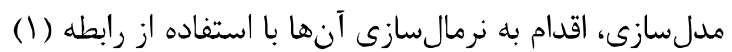

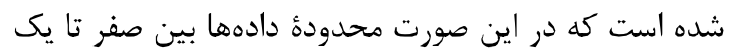

خواهد بود [25].

$$
x_{N}=\frac{x_{i}-x_{\min }}{x_{\text {max }}-x_{\text {min }}}
$$

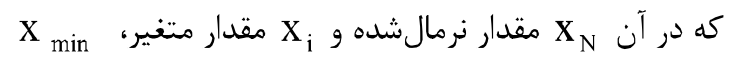

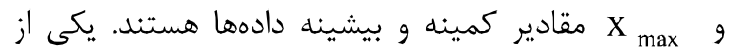

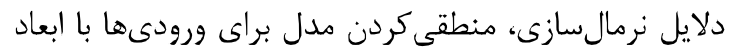

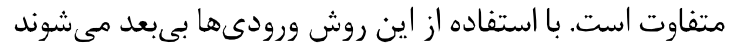

مدلهاى ARIMA توانايى تحليل و يِيشبينى دادههاى سرى

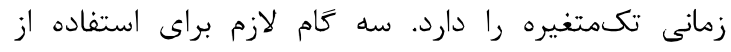
مدلهاى ARIMA شامل شناسايى، تخمين و بِيشبينى است. تابع مدل ARIMA بهصورت (p,d,q) نمايش داده مى شوند. بيان كر مر تبؤ عبارت خودهمبستخى، d مرتبأ تفاضل غيرفصلى

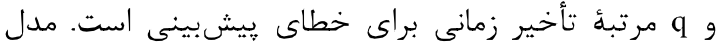

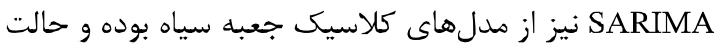
كلى مدل ARIMA است. اين مدل نيز خطى بوده و بر فرض ايستابودن دادهها استوار است. مدل SARIMA بر خلاف مداف

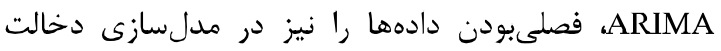
مى دهد. بهطور كلى سرى زمانى اصلى (y(t) از يكى إيراتور تأخير B براى مدل SARIMA(p,d,q)(P,D,Q) مى كند. (p,d,q) مربوط به قسمت غيرفصلى مدل و (P,D,Q) مربوط به قسمت فصلى مدل است.

\section{r-r-r - شبكههاى عصبى مصنوعى}

عملكرد مغز انسان با توجه به ميليونها سال تكامل مى تواند

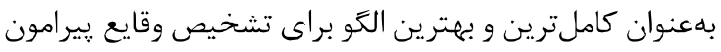

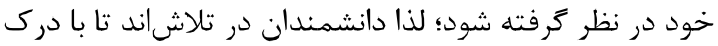
اصول و سازوكارهاى محاسباتى مغز انسان كه عملكرد بسيار

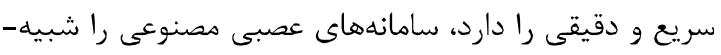

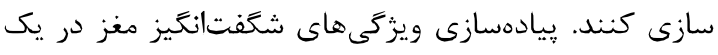

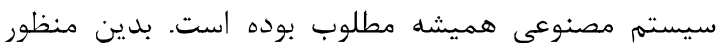
موضوع ايجاد هوش مصنوعى(

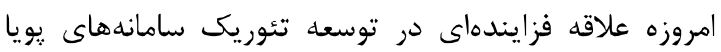

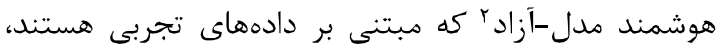

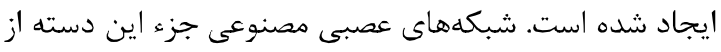

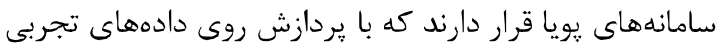

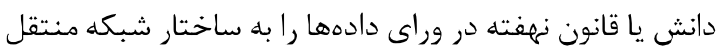

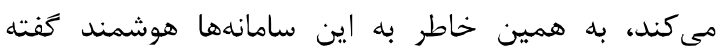

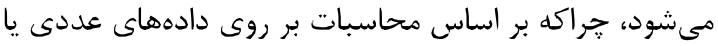

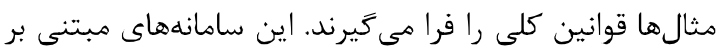

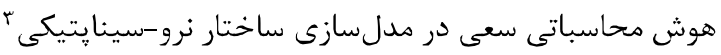

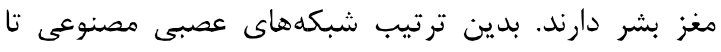

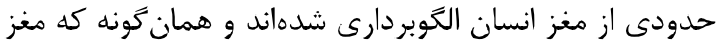

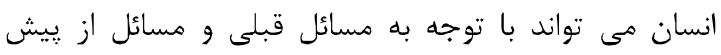

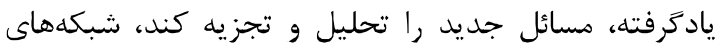

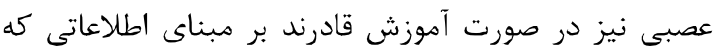

\footnotetext{
${ }^{1}$ Artificial Intelligence

${ }^{2}$ Model-Free

${ }^{3}$ Neuro-Synaptic
} 
عصبى تعيين مىشود؛ بنابراين ويزگى هاى هر دو مدل فازى

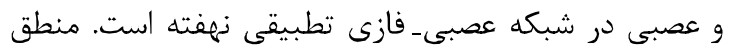
فازى بر مبناى تئورى مجموعههاى فازى قرار دارد كه بين

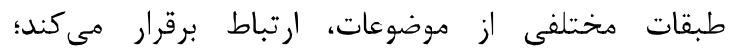

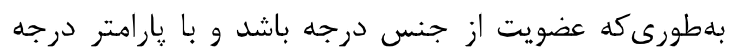

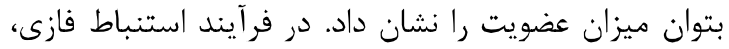

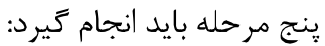
(1) فازىسازى متغيرهاى ورودى

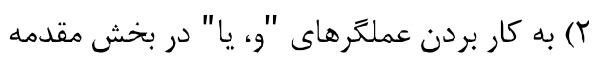
(ب) استنتاج از مقدمه به نتيجه

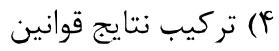
(a) غيرفازى كردن. بخش شبكه عصبى در ساختار شبكه عصبى- فازى

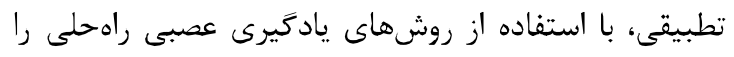

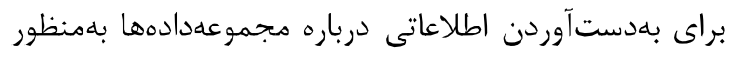

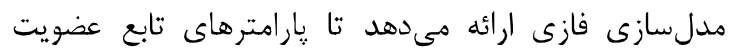

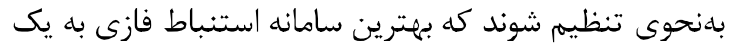

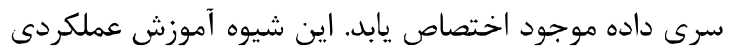
همانند شبكه عصبى دارد. روش مدلسازى بلوسيله سامانه استنباط فازى

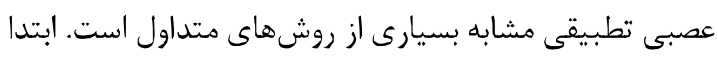
ساختار يك مدل با پار امترهاى مشخص (تابع و درجه عضويت)

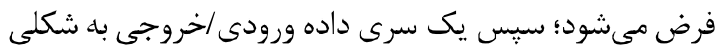

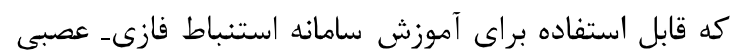

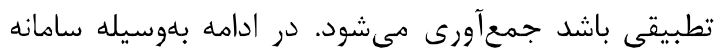

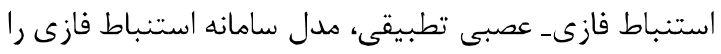

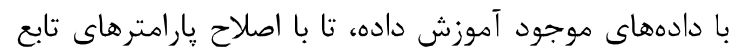
درجه عضويت مطابق با حد خطاى انتخابشده، دادههاى حاصل از مدل به مقدار واقعى نزديك شوند.

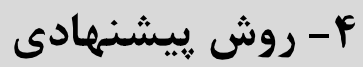

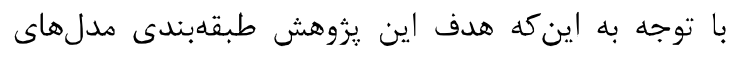

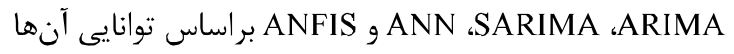
در كنترل اجزاء اصلى سرى زمانى، يعنى خودهمبستكى و و

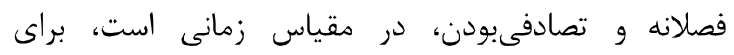
مدلسازى مراحل زير دنبال مىشودي

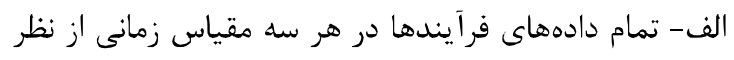
كيفيت دادها كنترل مىشوند.
و همجنين اختلاف فاحش عددى متغيرهاى مختلف از طريق نرمال سازى برطرف شده و دامنه دادهاى ورودى در بازه صفري تا يك خواهد بود.

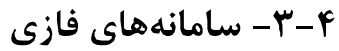

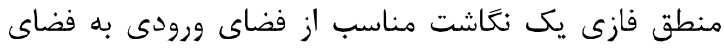

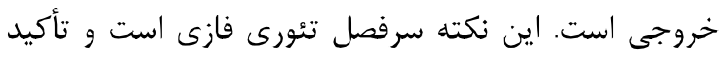

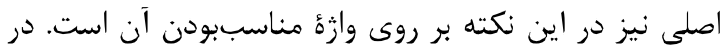

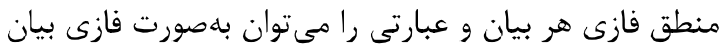

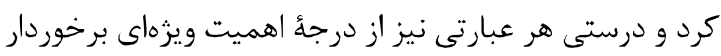

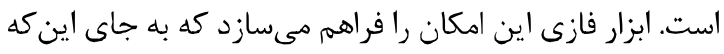

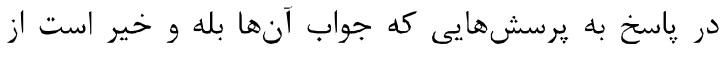

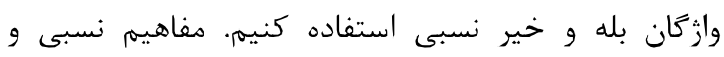

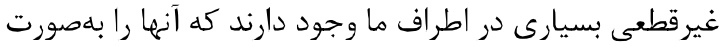

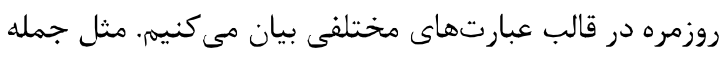

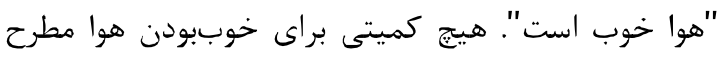

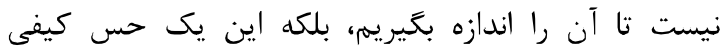

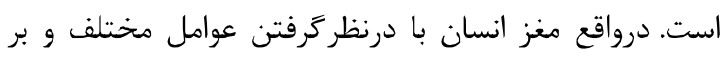

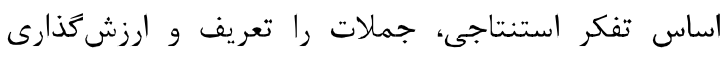

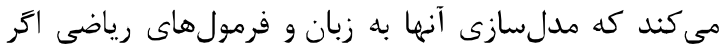

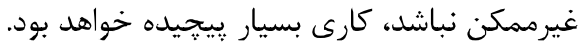

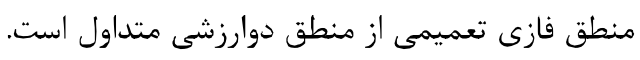
درحالى كه در منطق دودويى جايى براى وازمهايى همجئون

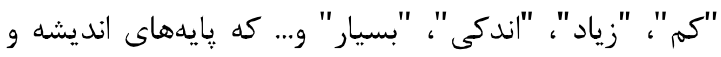

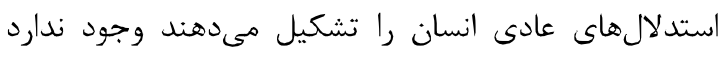
روش فازى بر مبناى بهكاركيرى همين عبارات زبانى است؛

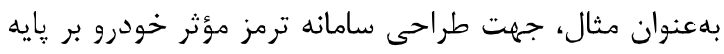

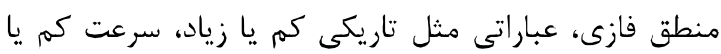

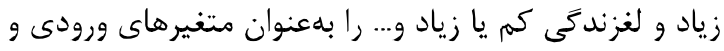

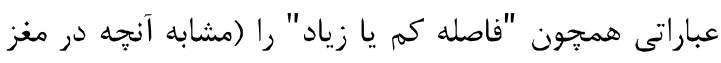

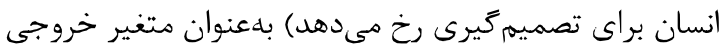
به كار مىبنديمه.

\section{ه-r- - مدل شبكه عصبي - فازى تطبيقى} در سال بو991، جانگ براى نخستينبار با كنار هم قراردادن توانايىهاى تئورى فازى و شبكه عصبى، مدل سامانه استتتاج

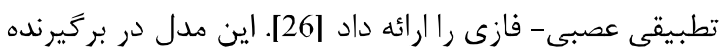

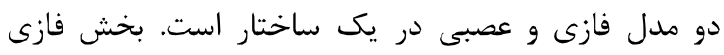

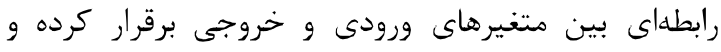
يارامترهاى مربوط به توابع عضويت بخش فازى بدوسيله شبكه 
ه- دادههاى مورد مطالعه

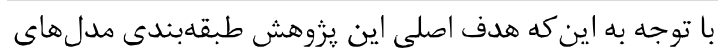

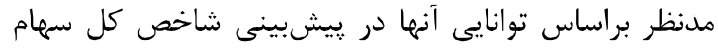

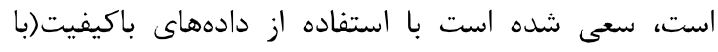

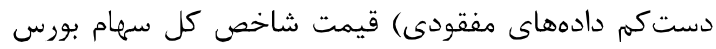
تهران و همجنين متغيرهاى مؤثر در قيمت شاخص كل سمهام

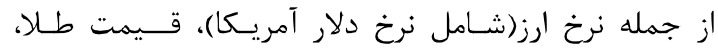

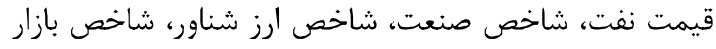

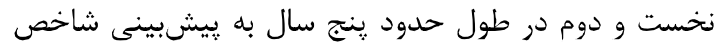

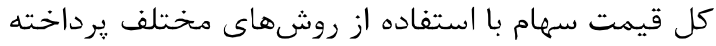
مى شود. دادهاى واقعى شاخص كل قيمت سهام در شكل (1)

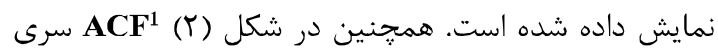
زمانى شاخص كل سهام نشان داده شده است كه بيانكر

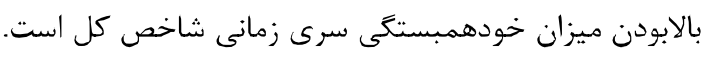

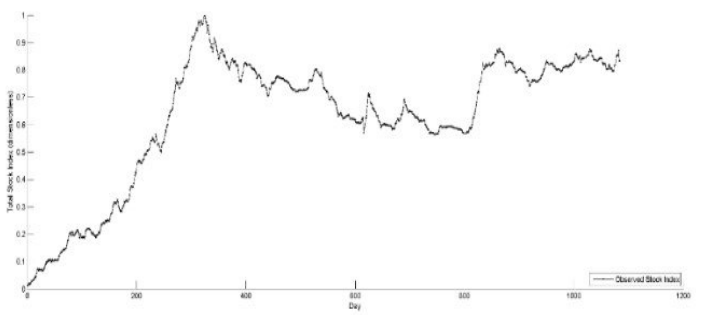

(شكل - (): دادههاى مشاهداتى شاخص كل سهام

(Figure-1): Observed data of the total stock index

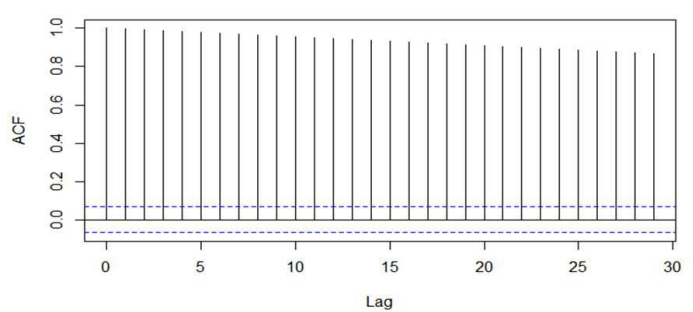

(شكل-Y): نمودار ACF زمانى شاخص كل سهام (Figure-2): The ACF chart of the total stock index

\section{9- نتايج حاصل از مدلسازىها}

در سه بخش زير نتايج حاصل از مدل سازىهاى صورتكرفتهه،

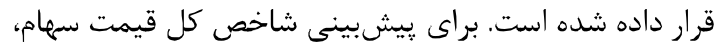

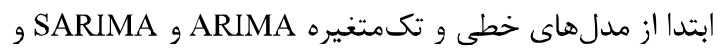

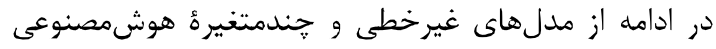

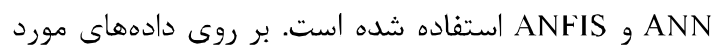

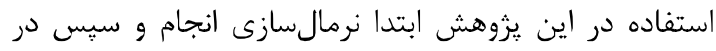

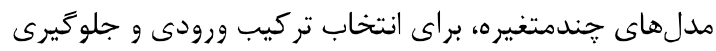

${ }^{1}$ Auto Correlation Function
ب- تمامى دادهها نرمال مىشوند تا در بازٔ صفر و يك قرار بخيرند.

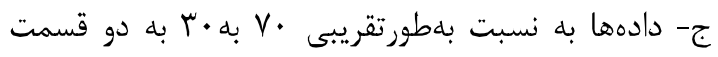
آموزش و صحتسنجى تقسيم مىشوند.

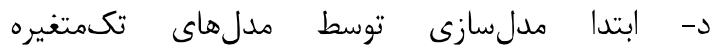
ARIMA,SARIMA

ه براى مدلسازى با مدل هاى جندمتغيره ANFIS ANN

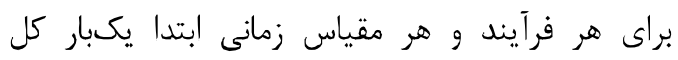

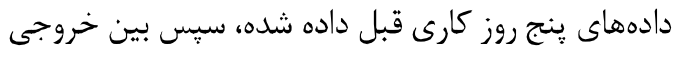
مدنظر و تمام سرىهاى مورد نظر ورودى ،دوبهدو، لC و محاسبه و بهترين تركيبهاى ورودى براساس اين دو

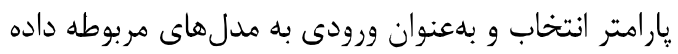
مىشوند و سيس مدل سازى صورت مى خيرد. براى انتخاب ورودى، در مرحله نخست از معيارى به مديه نام ضريب همبستگى خطى(CC)، استفاده شده است كه براى دو متغير X و از طريق زير محاسبه مىشود:

$$
\rho_{X, Y}=\frac{\sum(x-\bar{x})(y-\bar{y})}{\sqrt{\sum(x-\bar{x})^{2} \sum(y-\bar{y})^{2}}}
$$

$C C_{X, Y}=\left(\rho_{X, Y}\right)^{2}$

كه در اين روابط م ضريب همبستكى خطى بين دو متغير و

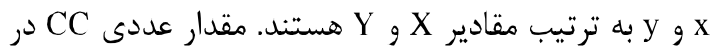
بازه صفر تا يك قرار مى كيرد و هرجه اين مقدار به يك له نزديكتر باشد، رابطه خطى بهترى بين دو متغير وجود دارد.

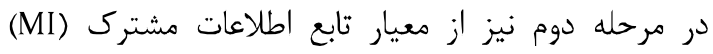
استفاده شده كه طبق تعريف رابطه زير همواره برقرار است: $\mathrm{MI}(\mathrm{X}, \mathrm{Y})=\mathrm{H}(\mathrm{X})+\mathrm{H}(\mathrm{Y})-\mathrm{H}(\mathrm{X}, \mathrm{Y})$

لازم به توضيح است كه H(X) و H(Y) با استفاده از رابطه (b)

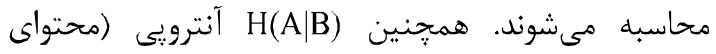

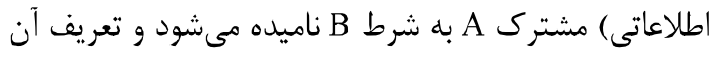
طبق رابطه (و) است: $\mathrm{H}(\mathrm{X})=\mathrm{H}(\mathrm{P})=-\sum_{i=1}^{N} \mathrm{p}\left(x_{i}\right) \log \left[\mathrm{p}\left(x_{i}\right)\right]$ $H(A \mid B)=-\sum_{a \in A, b \in B} p(a, b) \log p(A \mid B)$ و- در انتها تمامى مدلها براساس معيارهاى ارزيابى توضيح

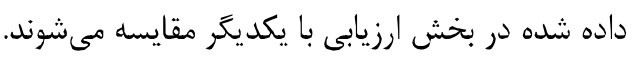


در اين يزوهش مدلسازى آنها با استفاده از نرمافزار Rورت كرفته است. براى مدلسازى شاخص كل سهام، بهترين ساختار مدلهاى ARIMA و SARIMA در جدول (1) آورده شده است.
از آزمون خطاهاى مختلف، از معيار CC خطى و معيار MI كه

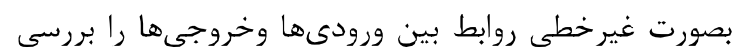
مى كند، استفاده شده است.

SARIMA, ARIMA مدلهاى ARIMA و SARIMA از مدلهاى جعبلهياه كلاسيك خطى و تكمتغيره و همجنين تكىتناوبه هستند كه

(جدول-1): نتايج حاصل از مدلسازى شاخص كل سهام توسط مدل SARIMA و ARIMA

(Table-1): The results of the total stock index modeling by ARIMA and SARIMA models

\begin{tabular}{|c|c|c|c|c|c|c|}
\hline \multicolumn{2}{|c|}{ RMSE(نرمال شده) } & \multicolumn{2}{|c|}{ Nash-Sutcliffe(E) } & \multirow[b]{2}{*}{ ساختار مدل } & \multirow[b]{2}{*}{ نوع مدل } & \multirow[b]{2}{*}{ مقياس زمانى } \\
\hline صحت سنجى & آموزش & صنجى & آموزش & & & \\
\hline 0.007 & 0.0062 & 0.9487 & 0.9589 & $\operatorname{ARIMA}(3,2,2)$ & ARIMA & 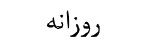 \\
\hline 0.0075 & 0.007 & 0.9578 & 0.9688 & $\operatorname{ARIMA}(3,2,2)(1,1,1)[7]$ & SARIMA & روزانه \\
\hline
\end{tabular}

شبكههاى عصبى از الخوريتم لونبرگ-ماركوارت استفاده شده است [22]

فرآيند آموزش شبكه زمانى متوقف مىشود كه ميزان

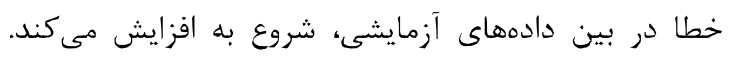

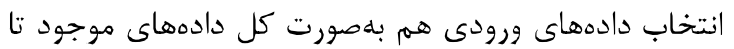
ينج روز كارى قبل و هم با استفاده از معيارهاى MI و MI انتخاب شده و مورد استفاده قرار زرفته است كه در معيار از مفهوم آنترويى استفاده مى كنيم كه ابزارى براى انتخاب ورودى به مدلهاى جندمتغيره است. بهترين ساختار مدل براى مدل ANN شده است. همان طور كه در جدول (Y) مشاهده مىشود، نتايج مدلسازى با ورودى تمام دادههاى ينج روز قبل كارى، جِندان

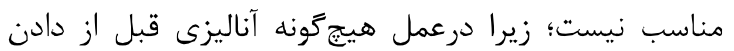
ورودىها به مدل صورت نگُرفته است و اين تعداد ورودى زياد باعث ايجاد خطاى بيشترى در مدلسازى مىشود؛ ولى نتايج بلدستآمده براى دادههاى ورودى منتخب با استفاده از معيارهاى MI و CC مناسب است؛ جون دادههايى كه با دهاي شاخص كل بورس رابطه غيرخطى نزديكترى دارند، انتخاب

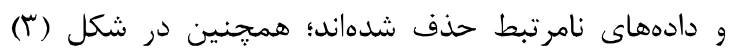
عملكرد ANN با سه نوع ورودى مختلف بررسى شده است، بدين صورت كه در قسمت صحتسنجى عملكرد هر سه مدل در يانزده روز دلخواه نشان داده شده است.
همانطوركة مشاهده ميشود براى مدلهاى ARIMA و نتايج بلنسبه مناسبى بهدست آمده خون با توجه مئه به ACF سرى زمانى شاخص كل (شكل ؟)، دادهاى ما داراى خاصيت خودهمبستغى در حد بالايى است؛ اما با اين وجود نتايج بهدستآمده بهنسبه مناسب است.

ANN مدل-

در مدل ANN، خروجى نهتنها به انتخاب مناسب متغيرهاى ورودى وابسته است، بلكه به درست تنظيمكردن وارامترهاى برنامه همانند توابع دحرك، تعداد نرونهاى ميانى و تعداد تكرار فرآيند آموزش شبكه نيز وابسته است. ساختار بهينه ANN مى آيد. هدف از اين آزمون و خطا، يافتن تعداد نرونهاى لايه ينهان و تعداد تكرار الكوريتهم است تا به واسطه آنها مدل تعريف شود. اين روند با استفاده از جعبه ابزار nntool نرمافزار MATLAB مىيذيرد. كَفتنى است كه تعداد تكرارهاى آموزشى كم مىتواند منجر به آموزش ناقص شود؛ لذا بايستى مقدار بهينهاى براى تعداد تكرارها در نظر كرفت تا كيفيت مدل براى

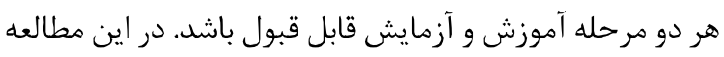
تعداد تكرارها از طريق آزمون و خطا در بازه ده تا دويست تعيين شد. به جهت قدرت همرايى زياد، براى آموزش 


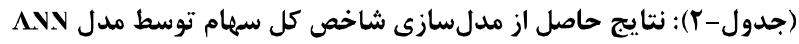

(Table-2): The results of the total stock index modeling by $\Lambda$ NN model

\begin{tabular}{|c|c|c|c|c|c|c|c|}
\hline \multicolumn{2}{|c|}{ RMSE(نرمال شده) } & \multicolumn{2}{|c|}{ Nash-Sutcliffe(E) } & \multirow{2}{*}{ تكرار } & \multirow{2}{*}{ ساختار مدل } & \multirow{2}{*}{ ورودى مدل } & \multirow{2}{*}{ متد انتخاب } \\
\hline صحتسنجى & آموزش & صحتسنجى & آموزش & & & & \\
\hline 0.0075 & 0.007 & 0.8890 & 0.9087 & 50 & $30-5-1$ & ALL DATA & ALL \\
\hline 0.0056 & 0.005 & 0.9770 & 0.9786 & 100 & $7-10-1$ & 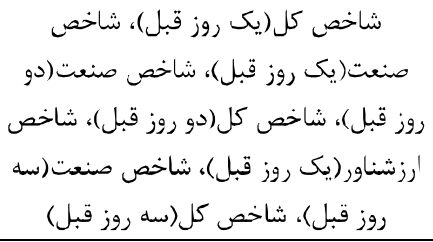 & MI \\
\hline 0.006 & 0.003 & 0.9682 & 0.9689 & 100 & $7-13-1$ & 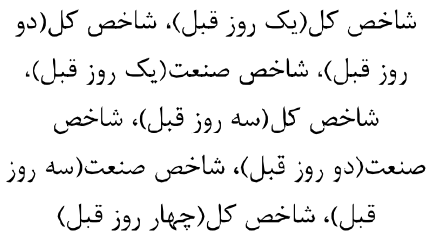 & $\mathrm{CC}$ \\
\hline
\end{tabular}

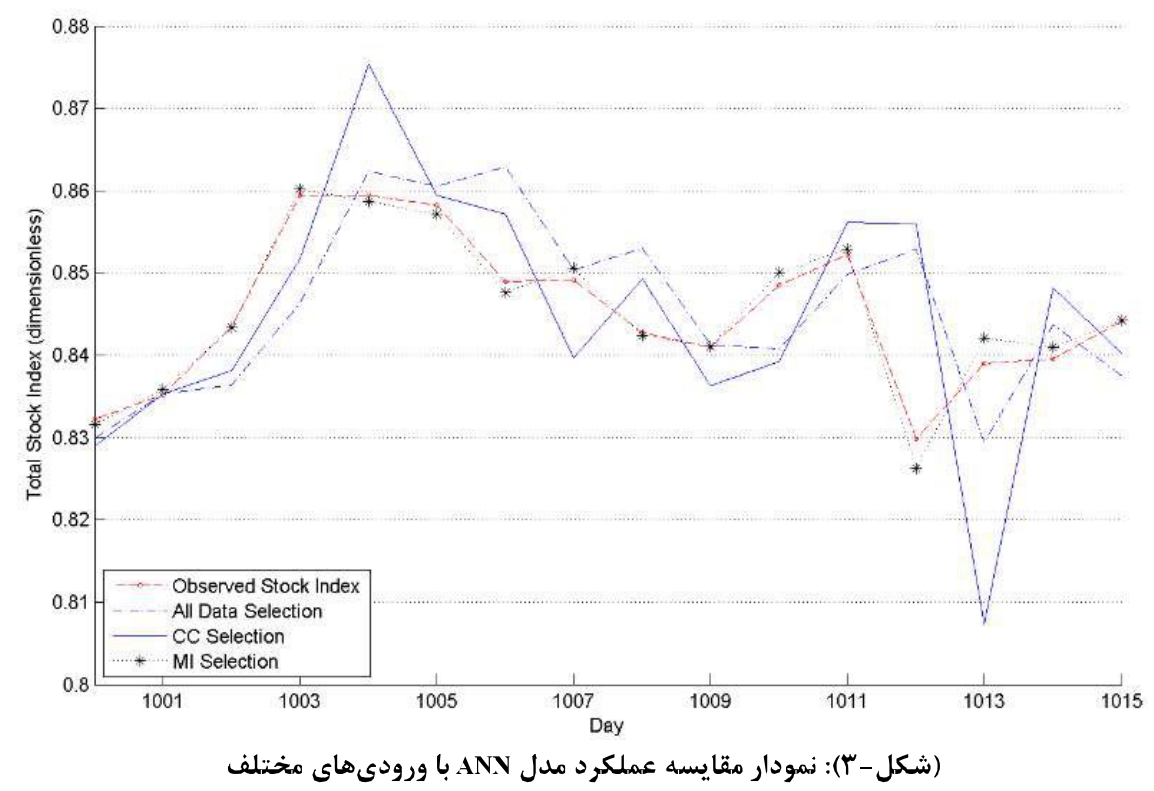

(Figure-3): The comparison chart of the ANN model performance with different inputs

نحوه مدلسازى با ANFIS نيز همانند ANN است با اين

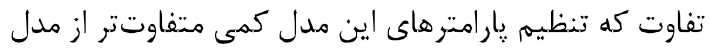

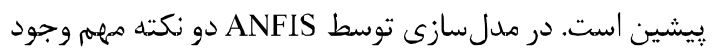
دارد كه بايد مورد توجه قرار بخيرد، اولى ساختار و تعداد توابع عضويت) و دومى تعداد تكرار جهت آموزش دورد بردي ANFIS كام آموزش و هم در گام سنجش منجر به ببهبود كارايى مدل

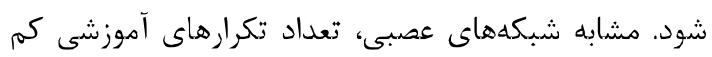

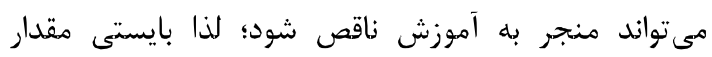
بهينهاى براى تعداد تكرارها در نظر زرفت تا كيفيت هدل براى
همانطوركه در شكل (T) مشاهده مىشود، عملكرد مدل ANN با ورودى MI در يِيشبينى نقاط بيشينه مناسبتر از ساير مدلها بوده و اين بهدليل در نظرگرفتن روابط غير خطى است.

\section{ANFIS مد مدر}

مدل ANFIS نوعى از مدلهاى شبكه عصبى مصنوعى بوده

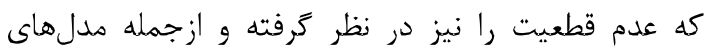
خودهمبسته است كه بهصورت غيرخطى امكان كنترل جزء خودهمبسته سرى زمانى را فراهم هى كند. اصول و روند كلى لى 
روند آزمون و خطا بهدست آمده و بهترين نتايج يادشده است.

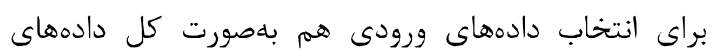
موجود تا ينج روزكارى قبل و هم از معيار MI و CC استفاده

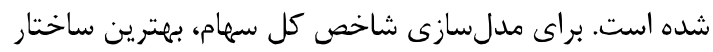
مدل ANFIS در جدول (Гا) آورده شده است.

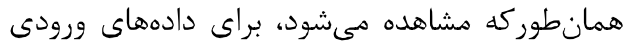

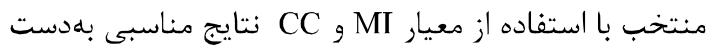

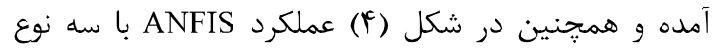

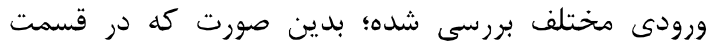

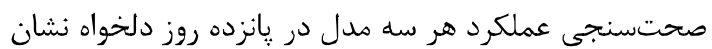

هر دو مرحله آموزش و آزمايش قابل قبول باشد. در مدل

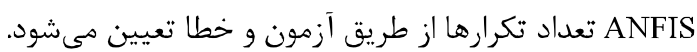

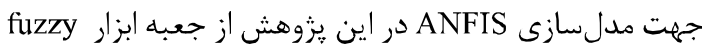
أرمافزار MATLAB logic فراخوانى MATFIS در محيط MATLAB از دستور

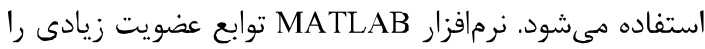

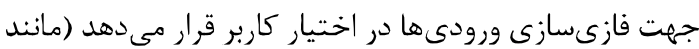

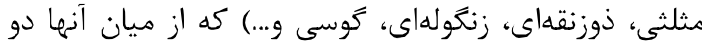

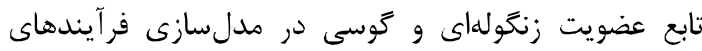

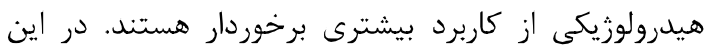
يزوهش جهت فازى كردن ورودىها از تابع عضويت زنتخولهاى

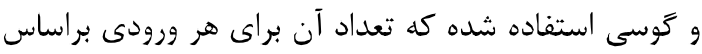

\begin{tabular}{|c|c|c|c|c|c|c|}
\hline \multicolumn{2}{|c|}{ RMSE(نرمال شده) } & \multicolumn{2}{|c|}{ Nash-Sutcliffe(E) } & \multirow{2}{*}{ ساختار مدل } & \multirow{2}{*}{ ورودى مدل } & \multirow{2}{*}{ متد انتخاب } \\
\hline صحت سنجى & آموزش & صحت سنجى & آموزش & & & \\
\hline 0.058 & 0.007 & 0.9578 & 0.9684 & كوسى -r & ALL DATA & ALL \\
\hline 0.004 & 0.002 & 0.9971 & 0.9997 & r-r كوسى & 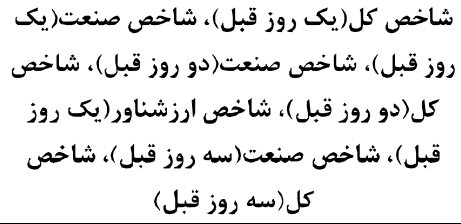 & MI \\
\hline 0.0045 & 0.003 & 0.9960 & 0.9982 & كوسى-r & 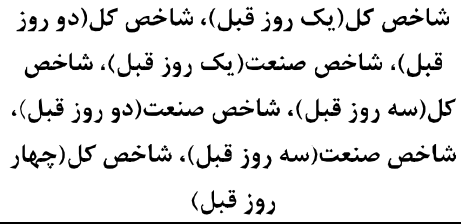 & $\mathrm{CC}$ \\
\hline
\end{tabular}

(جدول -r) نتايج حاصل از مدلسازى شاخص كل سهام بdوسيلهُ مدل ANFIS

(Table-3): The results of the total stock index modeling by the ANFIS model

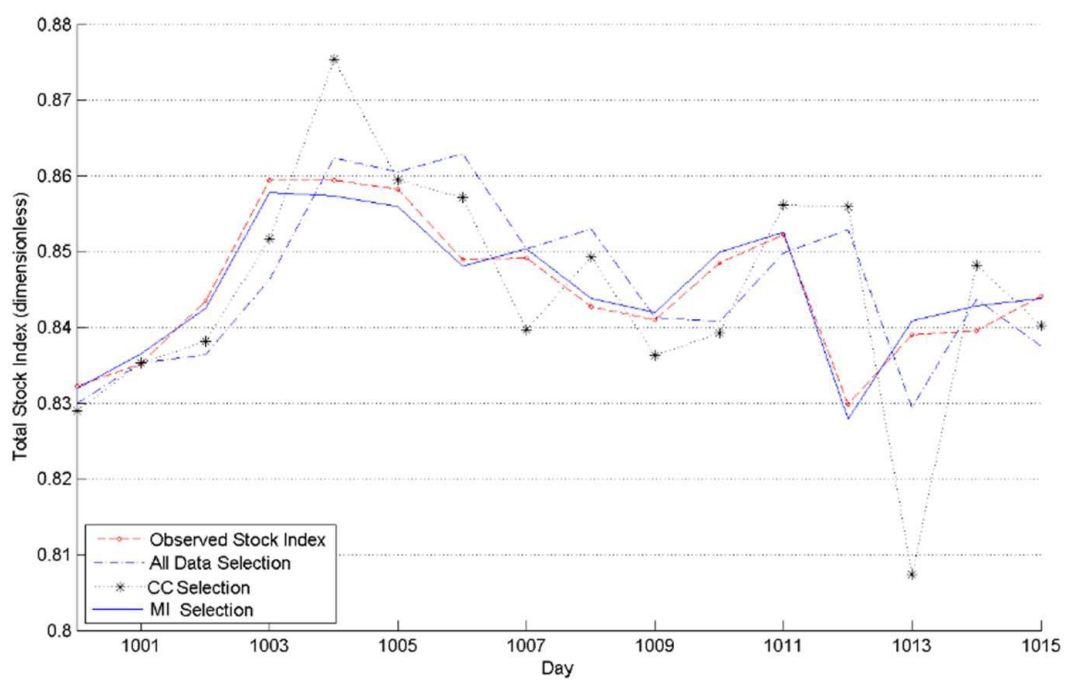

(شكل - f-): نمودار مقايسه عملكرد مدل ANFIS با ورودى هاى مختلف

(Figure-4): The comparison chart of the ANFIS model performance with different inputs 
همانطور كه در شكل (ه) مشاهده مىشود، براى مقايسه كل، بهترين مدل هاى ANN و ANFIS استفاده شده كه همان مدل هاى با ورودى روش MI هستند، انتخاب شده است. از ديد كلى با توجه به خودهمبستخى بالاى سرى زمانى استفادهشد (شكل r) همة مدل هاى استفادهده نتايج مناسبى را شامل شدهاند؛ اما همانطور كه در شكل (ع) مشاهده مى ميود، مدل ANFIS با ورودى روش MI در زيشبينى نقاط بيشينه بهتر

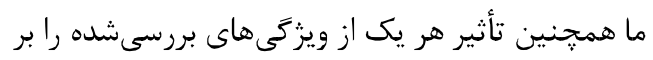

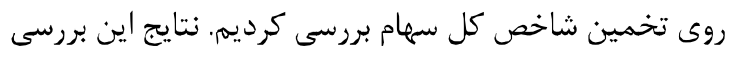

$$
\text { در جدولهاى (أ و ف) ارائه شده است. }
$$

همانطور كه در شكل (f) مشاهده مىشود، عملكرد مدل

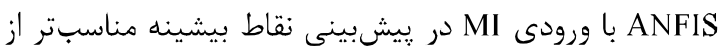
ساير مدلها بوده و اين بهدليل درنظرگرفتن روابط غيرخطى و عدم قطعيت است.

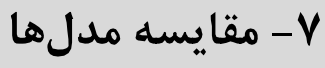

در اين قسمت نتايج حاصل از مدلسازىها در هرحله صحتسنجى مورد مطالعه و مقايسه قرار زرفته شده است و در

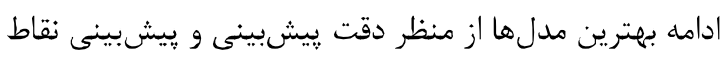
بيشينه (در مرحله صحتسنجى) مورد بررسى و مقايسه قرار

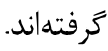

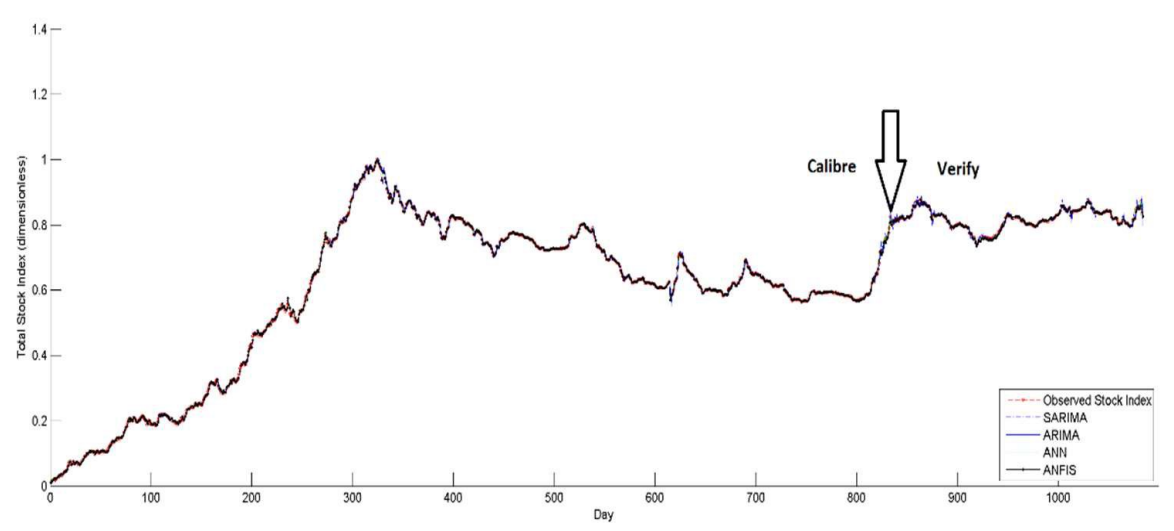

(شكل-ه): نمودار مقايسه نتايج حاصل از مدل سازىهاى صورت

(Figure-5): The comparison chart of the total stock index different models

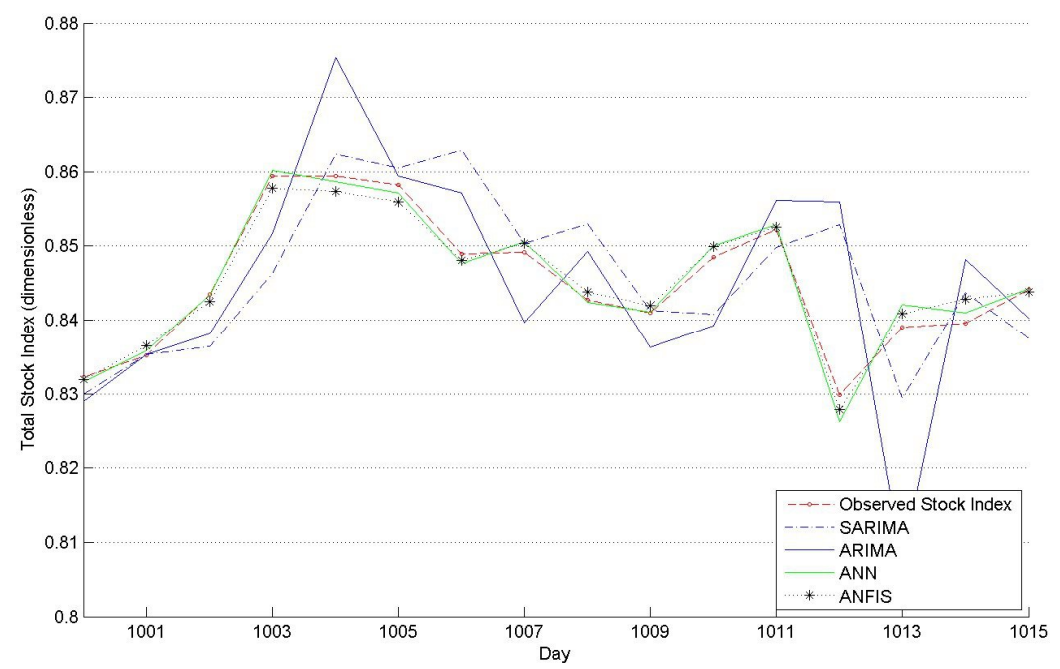

(شكل-4): نمودار جزييات مقايسه نتايج حاصل از مدلسازىهاى صورت (Figure-6): Details of the comparison chart of the total stock index different models 
(جدول - P): تأثير هر ويزٔى با استفاده از روش MI در تخمين شاخص كل سهام

(Table-4): The effect of each feature using the MI method in total stock index modeling

\begin{tabular}{|c|c|c|c|c|c|c|c|c|c|}
\hline يك روز قبل & جهار روز & جهار روز & سه روز قبل & سه روز قبل & يك روز قبل & دو زوز قبل & دو روز قبل & يك روز قبل & يك روز قبل \\
\hline شاخص بازار & شاخص كل & شاخص & شاخص كل & شاخصت & شاخص ارز & شاخص كل & شاخصت & شاخص & شاخص كل \\
\hline 1.3197 & 1.3206 & 1.3281 & 1.3500 & 1.3505 & 1.3536 & 1.3958 & 1.4052 & 1.4891 & 1.5034 \\
\hline سه روز قبل & دو روز قبل & يك روز قبل & ينج روز قبل & دو روز قبل & قهار روز & ينج روز قبل & ينج روز قبل & سه روز قبل & دو روز قبل \\
\hline شاخص بازار & شاخص بازار & شاخص بازار & شاخص ارز & شاخص بازار & شاخص ارز & شاخص & شاخص كل & شاخص ارز & شاخص ارز \\
\hline 1.2684 & 1.2708 & 1.2820 & 1.2838 & 1.2920 & 1.2971 & 1.3010 & 1.3030 & 1.3046 & 1.3163 \\
\hline يك روز قبل & قهبل روز & دو روز قبل & قجهاز روز & سه روز قبل & بنج روز قبل & ينج روز قبل & سه روز قبل & جبار روز & قهبل \\
\hline نفت & طلا & طلا & نفت & طلا & شاخص بازار & شاخص بازار & شاخص بازار & شاخص بازار & شاخص بازار \\
\hline 1.1537 & 1.1581 & 1.1583 & 1.1597 & 1.1644 & 1.2529 & 1.2602 & 1.2623 & 1.2630 & 1.2632 \\
\hline يك روز قبل & ينج روز قبل & دو روز قبل & جهار روز & سه روز قبل & دو روز قبل & سه روز قبل & يك روز قبل & ينج روز قبل & ينج روز قبل \\
\hline دلار & دلار & ل ل لار & دلار & دلار & نفت & نفت & طلا & طلا & نفت \\
\hline 0.8323 & 0.8348 & 0.8355 & 0.8383 & 0.8394 & 1.1384 & 1.1472 & 1.1478 & 1.1483 & 1.1530 \\
\hline
\end{tabular}

(جدول -ه): تأثير هر ويثكى با استفاده از روش CC در تخمين شاخص كل سهام

(Table-5): The effect of each feature using the $\mathrm{CC}$ method in the total stock index modeling

\begin{tabular}{|c|c|c|c|c|c|c|c|c|c|}
\hline يك روز قبل & ينج روز قبل & جهبل روز & جهار روز & سه روز قبل & دو روز قبل & سه روز قبل & يك روز قبل & دو روز قبل & يك روز قبل \\
\hline شاخص ارز & شاخص كل & شاخص & شاخص كل & شنعت & شاخص & شاخص كل & شاخص & شاخص كل & شاخص كل \\
\hline 0.9954 & 0.9955 & 0.9961 & 0.9967 & 0.9969 & 0.9977 & 0.9977 & 0.9982 & 0.9986 & 0.9994 \\
\hline ينج روز قبل & قجها: روز & سه روز قبل & لو روز قبل & يك روز قبل & ينج روز قبل & قجهار روز & سه روز قبل & دو روز قبل & ينج روز قبل \\
\hline شاخص بازار & شاخص بازار & شاخص بازار & شاخص بازار & شاخص بازار & شاخص ارز & شاخص ارز & شاخص ارز & شاخص ارز & شاخص \\
\hline 0.9829 & 0.9841 & 0.9852 & 0.9861 & 0.9869 & 0.9911 & 0.9924 & 0.9936 & 0.9946 & 0.9952 \\
\hline هنج روز قبل & جهار روز & سه روز قبل & دو روز قبل & يك روز قبل & ينج روز قبل & جهار روز & سه روز قبل & دو روز قبل & يك روز قبل \\
\hline دلار & دلار & دلار & دلار & دلار & شاخص بازار & شاخص بازار & شاخص بازار & شاخص بازار & شاخص بازار \\
\hline 0.7937 & 0.7956 & 0.7974 & 0.7991 & 0.8006 & 0.9641 & 0.9648 & 0.9653 & 0.9658 & 0.9662 \\
\hline ينج روز قبل & جهار روز & سه روز قبل & دو روز قبل & يك روز قبل & يك روز قبل & دو روز قبل & سه روز قبل & جهار روز & ينج روز قبل \\
\hline طلע & $V_{b}$ & bلا & bلا & bلا & نفت & نفت & نفت & نفت & نفت \\
\hline-0.7114 & -0.7106 & -0.7097 & -0.7088 & -0.7080 & -0.4618 & -0.4594 & -0.4570 & -0.4547 & -0.4524 \\
\hline
\end{tabular}


كل روزهاى قبل داشته باشند؛ اما قيمت طلا و دلار تأثير زيادى روى شاخص كل بورس نخواهد داشت.

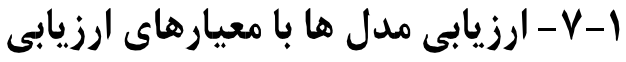

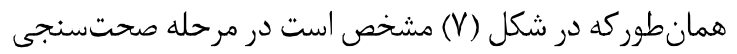

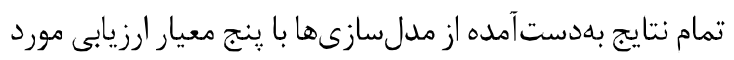

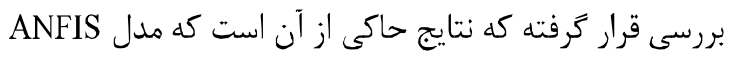

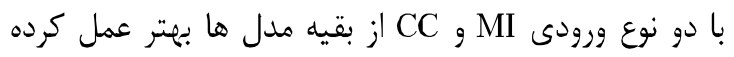

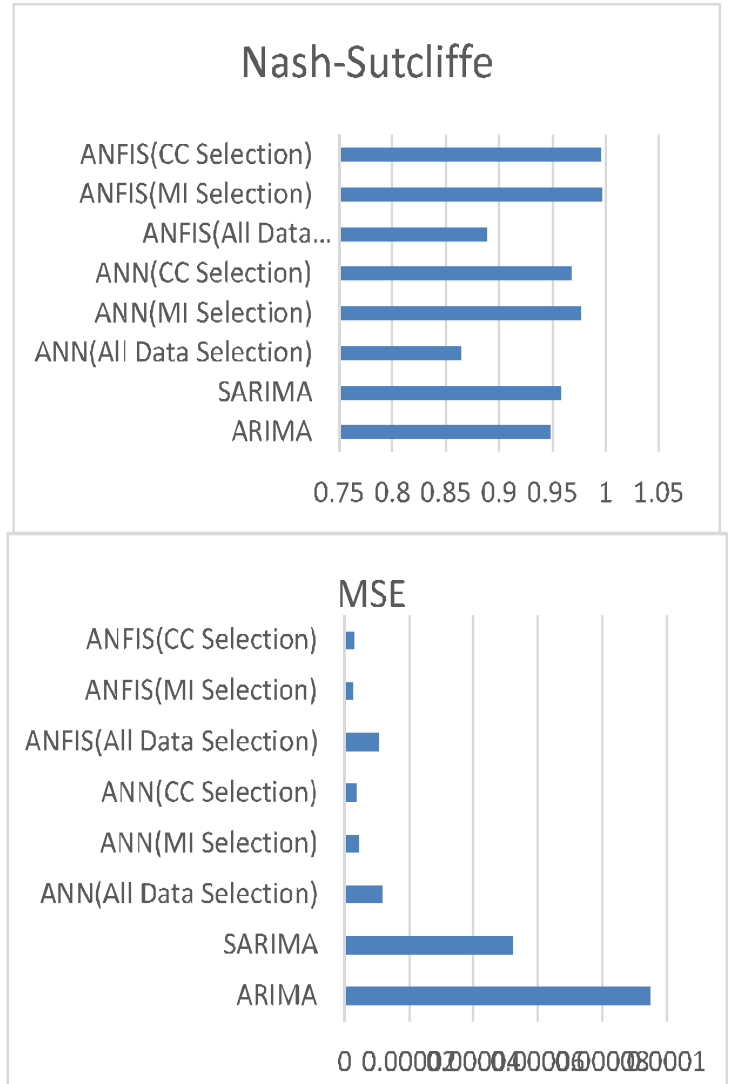

در جدول (\&) و جدول (ه) تأثير هر فيجر ورودى با استفاده از

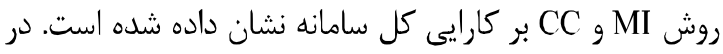
اين جدولها مقادير عددى طبق رابطه (ب و أ) محاسبه شدهاند.

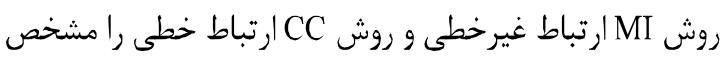
مى كند. همانطور كه مشاهده مىشود، ويزّى شاخص كل در

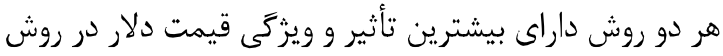
و و قيمت طلا در روش CC

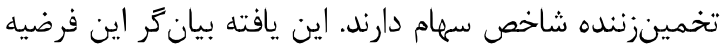
است كه سرمايهكذاران بورس براى موفقيت در كار خود و ييش -

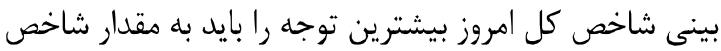
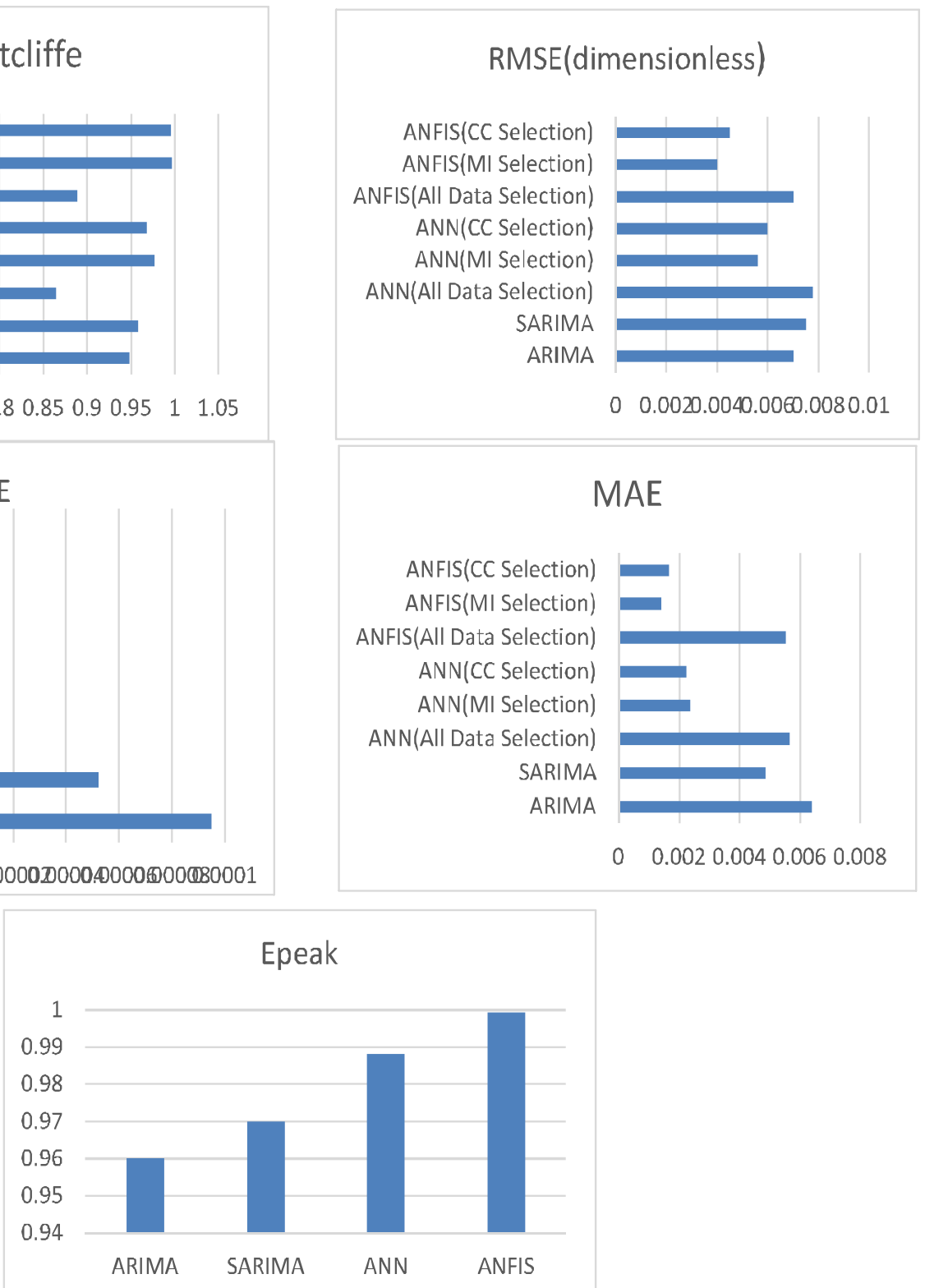

(شكل -V): نمودار مقايسه معيارهاى ارزيابى حاصل از مدل سازىهاى صورت كرفته براى يِيشبينى شاخص كل

(Figure-7): The comparison chart of the evaluation criteria in the total stock index

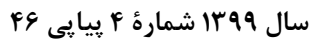


[4] M.Mahdavi, H.Ahaki, B.Nascrsharif. "Designing a Currency Recognition System Based on Neural Networks Using Texture and Color of Images," JSDP, 2011.

[5] G. A. Darbellay and M. Slama, "Forecasting the short-term demand for electricity," Internatıonal Journal of Forecastmg, vol. 16, no. 1, pp. 71 83, 2000 .

[6] T. Hill, L. Marquez, M. O'Connor, and W. Remus, "Artificial neural network models for forecasting and decision making," International Journal of Forecastıng, vol. 10, no. 1, pp. 5-15, 1994.

[7] D. Enke and S. Thawornwong, "The use of data mining and neural networks for forecasting stock market returns," Expert Systems with Application., vol. 29, no. 4, pp. 927-940, 2005.

[8] G. S. Atsalakis and K. P. Valavanis, "Forecasting stock market short-term trends using a neuro-fuzzy based methodology," Expert Systems with Application, vol. 36, no. 7, pp. 10696-10707, 2009.

[9] E. Guresen, G. Kayakutlu, and T. U. Daim, "Using artificial neural network models in stock market index prediction," Expert Systems with Application, vol. 38, no. 8, pp. 10389-10397, 2011.

[10] W. Qiu, X. Liu, and L. Wang, "Forecasting shanghai composite index based on fuzzy time series and improved C-fuzzy decision trees," Expert Systems with Application, vol. 39, no. 9, pp. 7680-7689, 2012.

[11] A. H. Moghaddam, M. H. Moghaddam, and M. Esfandyari, "Stock market index prediction using artificial neural network," Journal of Economics, Finance and Administrative Science, vol. 21, no. 41, pp. 89-93, 2016.

[12] M. Qiu, Y. Song, and F. Akagi, “Application of artificial neural network for the prediction of stock market returns: The case of the Japanese stock market," Chaos, Solitons \& Fractals, vol. 85, pp. 1-7, 2016.

[13] N. Tripathy, "Predicting Stock Market Price Using Neural Network Model," International Journal of Strategic Decision Sciences., vol. 9, no. 3, pp. 84-94, 2018.

[14] Z. IIajirahimi and M. Khashei, "IIybrid structures in time series modeling and forecasting: A review," Engineering Applications of Artificial Intelligence, DOI: https://doi.org/10.1016/j.engappai.2019.08.018 vol. 86, no.1, pp. 83-106, 2019.

[15] D. Selvamuthu, V. Kumar, and A. Mishra, "Indian stock market prediction using artificial neural networks on tick data," Financial Innovation, vol. 5, no. 6, 2019.

[16] J. Silva, J. V. Villa, and D. Cabrera, "Sale forecast for basic commodities based on artificial neural networks prediction," poceedings in

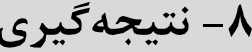

ֶِ از تحليل خروجى سامانه و دادههاى بلدستآمده در بخش ارزيابى، نتايج زير را استخراج كرديه:

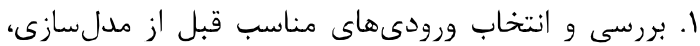

تأثير بهسزايى در بهبود نتايج مدلسازى دارد، بهخصوص

استفاده از روش MI براى انتخاب دادههاى ورودى.

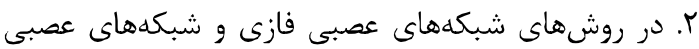

مصنوعى، انتخاب دادههاى ورودى با معيارهاى MI و CC، در بهبود نتايج تأثير بهسزايى داشته است.

r. مدل ANFIS از لحاظ ينج معيار ارزيابى عملكرد نسبت به

مدلهاى ديخر ارجحيت دارد؛ لذا بيشبينى سرى زئى زمانى

قيمت سهام با استفاده از شبكههاى عصبى فازى ميىتواند

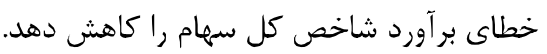

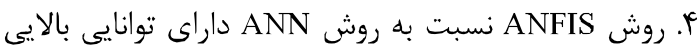

در شناخت الكوهاى حاكم بر دادهها دارد و در تمامى ينج

معيار ارزيابى عملكرد، شبكههاى عصبى فازى بر شبكههاى

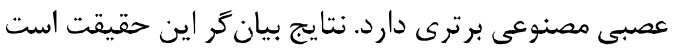

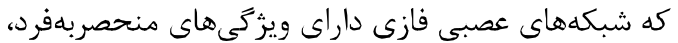

همَرايى سريع، دقت بالا و براى ييشبينى شاخص كل

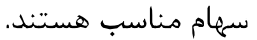

ه. هر دو روش هوش مصنوعى نسبت به روشهاى كلاسيك

نتايج بهترى نشان دادهاند و در تمامى ينج معيار ارزيابى

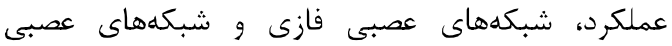

مصنوعى نسبت به روشهاى كلاسيك برترى دارد.

\section{9- References}

9 - مراجع

[1] B. K. Wong, T. A. Bodnovich, and Y. Selvi, "Neural network applications in business: A review and analysis of the literature (1988-1995)," Deciion Support Systems, vol. 19, no. 4, pp. 301320, 1997.

[2] T. Kimoto, K. Asakawa, M. Yoda, and M. Takeoka, "Stock market prediction system with modular neural networks," 1990 IJCNN International Join. Conference on Neural Networks, vol.1, pp. 1-6, 1990.

[3] G. Tkacz, "Neural network forecasting of Canadian GDP growth," Internatıonal Journal of Forecastıng, vol. 17, no. 1, pp. 57-69, 2001.

[4] م. مهلوى، ح. آهكى، ب. ناصرشريف. طراحى يك

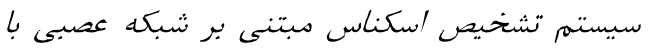

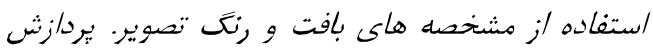

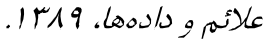




$$
\begin{aligned}
& \text { دريافت كرده است. زمينههاى يثوهشى مورد علاقه ايشان } \\
& \text { عبارتند از: شبكههاى عصبى و سامانههاى فازى است. } \\
& \text { نشانى رايانامه ايشان عبارت است ازئ }
\end{aligned}
$$

zhrpashaei@gmail.com

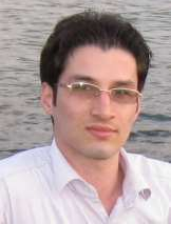

$$
\begin{aligned}
& \text { رحيم دهخوارقانى در سال هـ، مدرى } \\
& \text { كارشناسى خود را در رشته مهرندسى رايانه }
\end{aligned}
$$

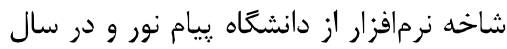

$$
\begin{aligned}
& \text { NV } \\
& \text { دانشعاه شهيد بهشتى در شاخه نرمافزار رشته مهندسى رايانه }
\end{aligned}
$$

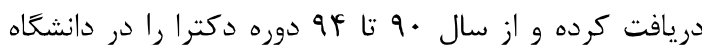

$$
\begin{aligned}
& \text { سابانجى استانبول (تركيه) در شاخه هوش مصنوعى گذرانيد. }
\end{aligned}
$$

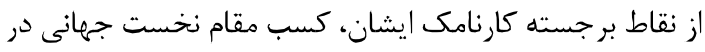

$$
\begin{aligned}
& \text { مسابقات SUMO Prize } 2007 \text { بdدليل ساخت بهترين } \\
& \text { آنتولوزى دامنه براى آنتولوزى SUMO توسط تيم دانشخاه } \\
& \text { شهيد بهشتى است. ايشان از سال هو عضو هيئت علمى بورى } \\
& \text { دانشخاه بناب در زروه مهندسى رايانه است. }
\end{aligned}
$$

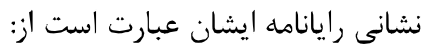

rdehkharghani@ubonab.ac.ir
Advances in Intelligent Systems and Computing, pp. 37-43, 2019.

[17] S. Chopra, D. Yadav, and A. N. Chopra, "Artificial Neural Networks Based Indian Stock Market Price Prediction: Before and After Demonetization," Journal of Swarm Inteligence Evolutionary Computation, vol. 8, no. 174, pp. 2, 2019.

[18] Jadhav S., Dange B., Shikalgar S. "Prediction of Stock Market Indices by Artificial Neural Networks Using Forecasting Algorithms". International Conference on Intelligent Computing and Applications. Advances in Intelligent Systems and Computing, vol. 632, Springer, Singaporc.

[19] T. Quoc Bao, L. Nhat Tan, L. Thi Thanh An, and B. Thi Thien My, "Forecasting stock index based on hybrid artificial neural network models," Science and Technology Deveelopment Journal Economics - Law and Management, vol. 3, no. 1, 2019.

[20] Ashik A.M., Kannan K.S. "Time Series Model for Stock Price Forecasting in India". In: Logistics, Supply Chain and Financial Predictive Analytics. Asset Analytics (Performance and Safety Management). Springer, Singapore, 2019

[21] R. S. Pressman, "Software Engineering A Practitioner's Approach". 7th Ed. - Roger S. Pressman. 2009.

[22] J. D. Salas, "Applied modeling of hydrologic time series", Water Resources Publication, 1980.

[23] G. E. P. Box, G. M. Jenkins, G. C. Reinsel, and G. M. Ljung, "Time series analysis: forecasting and control", John Wiley \& Sons, 2015.

[24] م. البرزى، آشنايى با شبكه هاى عصبى. انتشارات دانشعاه

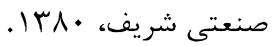

[24] M. Alborzi, “An introduction to Neural Networks." Sharif University of Technology, 2000.

[25] S. Alvisi, G. Mascellani, M. Franchini, and A. Bárdossy, "Water level forecasting through fuzzy logic and artificial neural network approaches," Hydrology and Earth System Sciences, vol. 10. pp. 1-17, 2006.

[26] J. S. R. Jang, " $\Lambda$ NFIS: $\Lambda$ daptive-NetworkBased Fuzzy Inference System," IEEE Transaction Systems, Man, and Cybernetics, vol. 23, no. 3, pp. $665685,1993$.

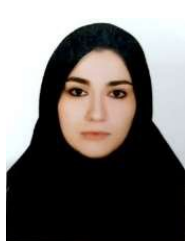

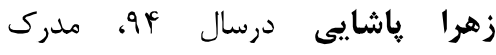

كارشناسى خود را در رشته مهندسى رايانه

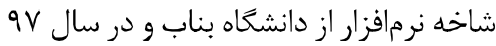

مدرك كارشناسى ارشد خود را از دانشكاه

آزاد در شاخه نرمافزار رشته مهندسى رايانه

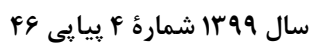

